\title{
RESENHA
}

\section{Mare Oceanus Atlanticus: Espaço de Diálogos*}

RAQUEL PATRÍCIO**

No âmbito da VIII Semana Cultural da Universidade de Coimbra (2 a 7 de Março de 2006), sob o título De Mar a Mar, especialistas diversos reuniram-se no Ciclo de Conferências Mare Oceanus Atlântico - Espaço de Diálogos, do qual resultou o livro com o mesmo nome. Coordenado pela Prof. Cat. Doutora Maria Manuela Tavares Ribeiro, da Universidade de Coimbra, publicado pela Almedina em Novembro de 2007, esta obra magistral sobre o Atlântico, a margem ocidental da Europa, conta com a participação dos Profs. Doutores Adriano Moreira (Universidade Técnica de Lisboa), Guilhermo Pérez Sánchez (Universidad de Valladolid), Ricardo Martín de la Guardiã (Universidad de Valladolid), Estêvão de Rezende Martins (Universidade de Brasília), Rui Cunha Martins e Cristina Robalo Cordeiro (ambos da Universidade de Coimbra).

Num momento em que a Europa procura definir com clareza a geografia da sua construção política, conjugando o alargamento com o aprofundamento, a dicotomia que sempre caracterizou a integração europeia, eis que surge uma literatura de alta qualidade sobre as fronteiras, geográficas e identitárias, da Europa, analisada sob o ponto de vista da simbiose entre europeidade e ocidentalidade culturais e entre europeísmo e atlantismo políticos.

Abordando o tema da solidariedade atlântica através de uma viagem pela história europeia e ocidental, Adriano Moreira refere a necessidade de existência de um inimigo comum para que essa solidariedade vingue. Foi o inimigo comum nos conflitos mundiais de 1914-18 e 1939-45 e, depois, face à ameaça sovietista durante a Guerra Fria, que determinou a pujança da solidariedade atlântica. Com queda do muro de Berlim em 1989, a desintegração da União Soviética em 1991 e o consequente fim da Guerra Fria, esse inimigo comum desapareceu, determinando que a solidariedade atlântica fosse substituída pela tendência soberanista e unilateralista dos Estados Unidos.

Não obstante, num primeiro momento, os Estados Unidos chegaram a apoiar os aliados europeus no enfrentamento dos novos desafios surgidos no Velho Continente. Como refere Guilhermo Sánchez, "mantener los vínculos

\footnotetext{
* RIBEIRO, Maria Manuela Tavares (Coord.). Mare Oceanus Atlanticus: Espaço de Diálogos. Coimbra: Almedina, 2007, 148 p. (ISBN 978-92-40-3221-4).

** Professora do Instituto Superior de Ciências Sociais e Políticas da Universidade Técnica de Lisboa, Portugal (raquelpatricio@iscsp.utl.pt).
} 
atlânticos euronorteamericanos" seria a melhor "garantia de estabilidad" (p. 33), especialmente para as novas democracias do Leste Europeu, provenientes da antiga dominação soviética.

Assim, enquanto a Europa Comunitária assumia as suas responsabilidades para com esses países - durante os anos 1990 estabelecendo ligações com os mesmos, em 2004 e 2007 aceitando-os em seu seio - os Estados Unidos reavaliavam a estrutura militar ocidental da era bipolar, primeiro incorporando, a partir de 1995, as novas democracias no Conselho de Cooperação do Atlântico Norte e, depois, ampliando a Aliança Atlântica (OTAN), em 1999 à Polónia, Hungria e República Checa e, em 2004, à Eslováquia, Eslovénia, Roménia, Bulgária, Letónia, Estónia e Lituânia.

É evidente que a extensão da OTAN às potências outrora pertencentes ao inimigo comum não esteve isenta de debate e discussão. Muitas foram as vozes que contra esse processo se levantaram, em nome da manutenção de uma lógica mental bipolar que queria, todavia, esvair-se. Do mesmo modo, o alargamento da União Europeia (EU) a esses países motivou controvérsias várias, levantando-se a questão de fundo de conhecer e dominar os limites da Europa. A noção de fronteira adquire, deste ponto de vista, singular pertinência, como bem salienta Rui Cunha Martins quando debate a integração europeia a partir da análise da definição, da mobilidade, da articulação e da regionalização das fronteiras na Europa Comunitária. Avaliando as lógicas subjacentes à capacidade da EU em absorver novos membros, a inevitabilidade de incorporar o elemento da circulação e o fenómeno do cruzamento de escalas, conclui Cunha Martins pelo ancoramento da construção europeia em níveis de sentido regionais. Por isso, depois de, a 4 de Maio de 2004, ter recebido de braços abertos a Polónia, a Hungria, a República Checa, a Eslováquia, a Eslovénia, a Letónia, a Lituânia, a Estónia, Chipre e Malta e de, a 1 de Janeiro de 2007, ter passado a incorporar também a Bulgária e a Roménia, a EU não deixará de fora a Croácia, a Bósnia-Herzegovina, a Sérvia, a Macedónia, agora também o Kosovo, a Turquia e por que não as ex-repúblicas soviéticas? Porque, retomando as ideias de Frank Pfetsch ((PFETSCH, 2002) e de Estêvão de Rezende Martins (MARTINS, 2002), a essência da Europa fundase nas raízes culturais de Atenas e Jerusalém (STEINER, 2005: 40). Porque " $a$ Europa é feita de cafetarias, de cafés. Estes vão da cafetaria preferida de Pessoa, em Lisboa, aos cafés de Odessa frequentados pelos gangsters de Isaac babel. Vão dos cafés de Copenhaga, onde Kierkegaard passava nos seus passeios concentrados, aos balcões de Palermo. Não há cafés antigos ou definidores em Moscovo (...) Poucos em Inglaterra (...) Nenhuns na América do Norte (...) Desenhe-se o mapa das cafetarias e obterse-á um dos marcadores essenciais da ideia de Europa" (STEINER, 2005: 26).

Assim a Europa Unida, seguindo os passos da Aliança Atlântica, tem vindo a incorporar as novas democracias do Leste Europeu em seu seio. O consenso euronorte-americano relativamente à necessidade de apoiar estas novas democracias foi determinante para a manutenção da solidariedade atlântica no período 
imediatamente após o desaparecimento do inimigo comum de que nos fala Adriano Moreira. A própria Administração Clinton deu mostras de reconhecer esta importância quando, em Junho de 1995, em discurso em Madrid, a Secretária de Estado Madeleine Albright formulou a Nova Agenda Transatlantica para o século XXI. O mesmo seria demonstrado em Dezembro de 1995 com a elaboração, entre a Europa e os Estados Unidos, do Plano de Acção Conjunta. Defendendo a democracia, o Estado de direito, a estabilidade e a segurança mundiais, a luta contra o tráfico de drogas, contra a emigração ilegal e contra o terrorismo, o Plano pretendia converter o marco atlântico num ponto privilegiado de melhoria das relaçōes do Atlântico Norte com outras áreas geográficas, jogando um papel decisivo no interesse da Europa e dos Estados Unidos em dar um "impulso vivificador" (p.142), na expressão de Ricardo de la Guardia, às relações transatlânticas, assim mantendo e, até, reforçando a solidariedade atlântica.

Não muito depois, os Estados Unidos de George Bush filho passariam a ditar sozinhos as regras do jogo internacional. Esquecidos dos aliados europeus e em guerra aberta contra o Eixo do Mal, logo após o ataque terrorista ao coração do american way of life em 2001, os Estados Unidos transitavam para o unilateralismo.

Os desastres deste unilateralismo norte-americano, todavia, têm tornado evidente a urgência dos ocidentais retornarem ao atlantismo, o "núcleo duro", segundo Adriano Moreira, "de uma concepção do mundo e da vida pronto para o diálogo" e "determinado a salvaguardar os seus valores" (p. 141), em nome de uma governança mundial que estruture os grandes espaços e os poderes emergentes caracterizadores da actual sociedade internacional global de Hedley Bull em torno do "único lugar do mundo onde todos se encontram com todos, fazendo do diálogo o instrumento da possivel tolerância, respeito e cooperaçãa" (p. 24), a fórmula de Adriano Moreira para referir-se às Nações Unidas.

É neste sentido que Estêvão de Rezende Martins reflecte sobre as duas vertentes do espaço atlântico - a dos processos de interacção em rede e a que estabelece as correlações entre os espaços constituídos em economias-mundo ou impérios-mundo, relembrando as teses de Immanuel Wallerstein sobre as origens da economia-mundo europeia no século XVI (WALLERSTEIN, 1974: 490) - concluindo que "a conformação dos espaços por processos materiais e imateriais representa, no caso do Atlântico, um factor de transformação social e institucional a tal ponto profundo que se pode falar de uma revolução atlântica" (p. 143).

Analisando a conformação das fronteiras ou dos traços-de-união nos espaços globais, sugere também Estêvão de Rezende Martins a congregação da solidariedade atlântica no seio das Nações Unidas, especialmente por ter sido o domínio do Atlântico "um passo decisivo para a criação de mundos globalizados" (p. 112). O mesmo Atlântico que Cristina Robalo Cordeiro aborda sob o ângulo da literatura francesa, a "porta-voz da Europa Atlântica" (p. 144), dizendo que "ideia para os (neo-) clássicos", o Atlântico foi "sentimento para os românticos (...) e tornou-se agora finalmente uma sensação" (p. 144). Uma sensação que deve 
ser explorada como espaço de contacto de uma simbiose mundial que defina a pertença de todos a um espaço transnacional e transcontinental, numa mescla de culturas e civilizações que permita, na expressão de Estêvão de Rezende Martins, que o "espaço de contacto, sob as condições de uma globalização que se define para além do mundo atlântico", não se transforme num "espaço cortado por fronteiras" (p. 112). Infelizmente, Mare Oceanus Atlântico: Espaço de Diálogos chega à conclusão contrária. Embora faça a apologia da solidariedade atlântica como o dever ser que ainda não é.

Recebido em 29 de Março de 2008 Aprovado em 15 de Junho de 2008 